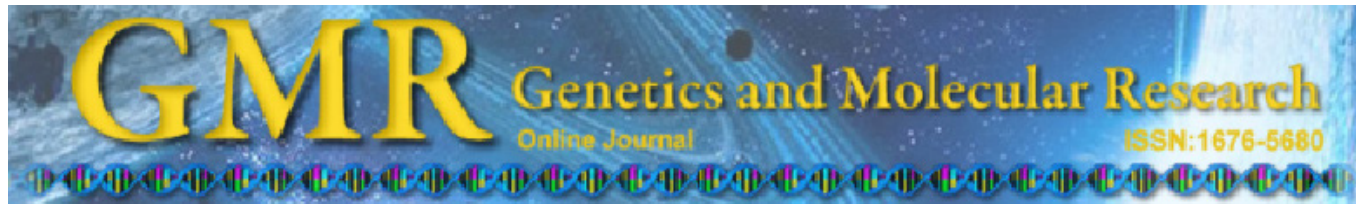

\title{
Genetic diversity and differentiation of exotic and American commercial cattle breeds raised in Brazil
}

B.S.A.F. Brasil ${ }^{1,2,3 *}$, E.G.A. Coelho ${ }^{1 *}$, M.G. Drummond ${ }^{1,2}$ and D.A.A. Oliveira ${ }^{1}$

${ }^{1}$ Laboratório de Genética Animal, Departamento de Zootecnia, Escola de Veterinária, Universidade Federal de Minas Gerais, Belo Horizonte, MG, Brasil

${ }^{2}$ Myleus Biotechnology Research Team, Belo Horizonte, MG, Brasil

${ }^{3}$ Embrapa Agroenergia, Brasília, DF, Brasil

*These authors contributed equally to this study.

Corresponding author: B.S.A.F. Brasil

E-mail: brunosafb@gmail.com / bruno.brasil@embrapa.br

Genet. Mol. Res. 12 (4): 5516-5526 (2013)

Received August 17, 2012

Accepted November 22, 2012

Published November 18, 2013

DOI http://dx.doi.org/10.4238/2013.November.18.2

\begin{abstract}
The Brazilian cattle population is mainly composed of breeds of zebuine origin and their American derivatives. Comprehensive knowledge about the genetic diversity of these populations is fundamental for animal breeding programs and the conservation of genetic resources. This study aimed to assess the phylogenetic relationships, levels of genetic diversity, and patterns of taurine/ zebuine admixture among 9 commercial cattle breeds raised in Brazil. Analysis of DNA polymorphisms was performed on 2965 animals using the 11 microsatellite markers recommended by the International Society of Animal Genetics. High genetic diversity was detected in all breeds, even though significant inbreeding was observed within some. Differences among the breeds accounted for $14.72 \%$ of the total genetic variability, and genetic differentiation was higher among taurine than among zebuine cattle. Of note, Nelore cattle presented with high levels of admixture, which is consistent with the history of frequent gene flow
\end{abstract}


during the establishment of this breed in Brazil. Furthermore, significant genetic variability was partitioned within the commercial cattle breeds formed in America, which, therefore, comprise important resources of genetic diversity in the tropics. The genetic characterization of these important Brazilian breeds may now facilitate the development of management and breeding programs for these populations.

Key words: Brazilian cattle; Genetic diversity; American cattle breeds; Population structure; Microsatellite markers

\section{INTRODUCTION}

Cattle are key domestic livestock species introduced in the Neotropics during colonization. These animals fulfill important roles in agriculture, economy, and culture. Taurine cattle (Bos taurus) were brought from Spain and Portugal to the American continent from the early 16th century (Jaeger, 1943) to the late 18th century (Salazar and Cardozo, 1986). In the course of a few years, these animals were taken to the south of North America, as well as to Central and South America, comprising the so called Creole cattle breeds. During the 19th and 20th centuries, zebu cattle (Bos indicus) and crossings were imported from India, especially to Brazil (Santiago, 1985). Since then, several breeds were formed through crossings in the American continent, e.g., the American zebuine breeds Brahman, Indubrasil, Nelore, and Tabapuã, the American taurine breed Senepol, and the zebuine/taurine synthetic breed Girolando.

Brazil holds the world's largest commercial cattle herd, estimated to be composed of 210 million animals in 2012 (IBGE, http://www.ibge.gov.br). Currently, the majority of the herd comprises exotic breeds of both taurine and zebuine origins and their American derivatives that were imported during the last 100 years (Cervini et al., 2006). The improvement of cattle in Brazil has frequently involved crossings between zebu and taurine cattle as well as between different zebu breeds (Dani et al., 2008). This occurred due to the better adaption of zebuine breeds to tropical ecological settings than taurine breeds. Since the second half of the 20th century, Brazil has been the center for zebu cattle distribution in Central and South America; thus, Brazil plays an important role as a resource of cattle genetic diversity in the tropics (Lirón et al., 2006).

Recent studies evaluated the genetic structure and diversity of locally adapted Creole cattle and some commercial breeds in Brazil and other Latin American countries (Cervini et al., 2006; Lirón et al., 2006; Egito et al., 2007; Dani et al., 2008; Delgado et al., 2012). The data reported indicate that variable patterns of breed admixture have occurred since colonial times that have shaped the current genetic status of the local breeds. These studies, together with data reported from cattle herds from different parts of the world (Tapio et al., 2006; Li et al., 2007; Li and Kantanen, 2010), provide valuable large datasets for several applications in animal breeding and conservation.

Despite the studies conducted in Eurasian cattle (B. taurus) and the growing body of data for Creole breeds, there remain gaps in our knowledge about the genetic diversity and population structure of economically important zebu and taurine cattle raised in Brazil. Especially, data related to conspicuous breeds developed in America during the 20th century, e.g., Nelore, Brahma, and Senepol, are scarce. In addition, strong directional selection has shaped 
commercial bovine populations in Brazil for decades, possibly leading to significant reductions in the effective population size (Egito et al., 2007; Dani et al., 2008).

Microsatellite markers have been widely used for population genetic analyses of livestock species. These markers are informative and can successfully elucidate the migration and admixture patterns of cattle breeds during their domestication. In addition, these markers are useful to assess intrapopulation diversity, genetic differentiation, and the relationships among modern cattle populations (Tapio et al., 2006; Li et al., 2007; Ginja et al., 2010).

In the present study, we used microsatellite markers to characterize the genetic diversity of 9 commercial breeds raised in Brazil. The survey mainly focus on five breeds formed on the American continent: Brahman, Nelore, Tabapuã, Senepol, and Girolando. The patterns of gene admixture and the phylogenetic relationships among these breeds and European and Indian cattle breeds were also evaluated.

\section{MATERIAL AND METHODS}

\section{Animals}

Nine Brazilian bovine commercial breeds were analyzed, involving 2965 animals. The studied breeds can be classified into American zebuine breeds (Brahman, Nelore, and Tabapuã), American taurine breed (Senepol), American zebuine/taurine (Gyr crossed with Holstein) crossbreed (Girolando), Indian zebuine breeds (Gyr and Guzerat), and European taurine breeds (Holstein and Jersey). Total genomic DNA was extracted using a standard salting-out protocol (Miller et al., 1988).

This study was approved by the Ethics Committee of the Universidade Federal de Minas Gerais and followed the legal requirements set by the Genetic Heritage Management Council of the Brazilian Ministry of the Environment.

\section{Microsatellite marker typing}

Fluorescently labeled primers for 11 dinucleotide microsatellites (TGLA227, BM2113, TGLA53, ETH10, TGLA126, TGLA122, INRA23, ETH3, ETH225, BM1824, and SPS115) were used. These markers are recommended by the International Society for Animal Genetics (ISAG)/Food and Agriculture Organization of the United Nations (FAO) working group (FAO, 2011) to carry out tests for genetic diversity and parentage in bovines.

Polymerase chain reaction (PCR) was carried out using $5 \mu \mathrm{L}$ Finnzymes/Phusion Flash master mix (Vantaa, Finland), $2.5 \mu \mathrm{L}$ multiplexed primers (as recommended by ISAG/ FAO), $1.5 \mu \mathrm{L}$ ultrapure water, and $1.0 \mu \mathrm{L}$ purified DNA. The amplified products were separated using capillary electrophoresis in an ABI Prism 3130 Genetic Analyzer (Applied Biosystems, California, USA). The results of the electrophoresis were analyzed using the GeneMapper software (Applied Biosystems, USA). The allele names were assigned using the reference samples of the ISAG inter-laboratories test 2010.

\section{Data analysis}

Calculations of allele frequencies, total number of alleles $\left(N_{\mathrm{A}}\right)$, effective number of alleles $\left(N_{\mathrm{E}}\right)$, observed number of alleles $\left(H_{\mathrm{O}}\right)$, and unbiased expected $\left(H_{\mathrm{E}}\right)$ heterozygosity per 
locus were calculated using the EXCEL MICROSATELLITE TOOLKIT (Park, 2002). The amount of inbreeding within a population (f) and the amount of differentiation among populations $(\theta)$ per locus, as well as the total deficit of heterozygotes $(\mathrm{F})$ were estimated according to Weir and Cockerham (1984). The FSTAT package (Goudet, 1995) was used to perform these calculations, with corresponding $P$ values obtained based on 10,000 randomizations.

Within-breed diversity was ascertained by measuring the mean number of alleles, average gene diversity, and observed and unbiased expected estimates of heterozygosity per population (Nei, 1973). The parameters and their standard deviations were calculated using the ARLEQUIN package (Excoffier et al., 2005). Deviations from Hardy-Weinberg equilibrium (HWE) were also assessed. The within breed inbreeding coefficient $\left(F_{\text {IS }}\right)$ was estimated with a $95 \%$ confidence interval, determined by 10,000 permutations using the ARLEQUIN package (Excoffier et al., 2005). The effective number of alleles per population $\left(N_{\mathrm{E}}\right)$ was calculated using FSTAT (Goudet, 1995) as a measure of the number of equally frequent alleles needed to achieve a given level of genetic diversity. This estimate allows the comparison of populations in which the number and distributions of alleles differ drastically. Average gene diversity was estimated as a measure of the number of alleles independently of the sample size, hence allowing comparisons among different sample sizes.

A hierarchical analysis of variance was carried out, which allowed the partitioning of the total genetic variance into components due to inter-individual and inter-breed differences. Variance components were used to compute fixation indices. The interpretation of population structure by F-statistics was tested using a non-parametric permutation approach (Excoffier et al., 1992). Computations were carried out using analysis of molecular variance (AMOVA) procedure within the ARLEQUIN package (Excoffier et al., 2005). Genetic divergence among breeds was estimated through 2 commonly used genetic distance measures: the Nei DA (Nei et al., 1983) and pairwise $F_{\mathrm{ST}}$ genetic distances using the GENECLASS 2.0 (Piry et al., 2004) and the ARLEQUIN (Excoffier et al., 2005) software, respectively. A NeighborNet was constructed from the Nei DA genetic distances to represent the relationships between breeds graphically using the SPLITSTREE 4 software (Huson and Bryant, 2006).

The genetic structure of the 9 cattle populations was investigated to identify population substructure and admixture. The grouping of individuals was tested assuming an increasing number of clusters $(\mathrm{K})$ and assigned probabilistically to clusters inferred with a Bayesian approach implemented using the STRUCTURE software (Pritchard et al., 2000). Runs of 500,000 iterations after a burn-in period of 200,000 iterations were performed for each K. Five independent simulations for $\mathrm{K}$ equal to $1-10$ were performed to identify the most probable $\mathrm{K}$ by determining the modal distribution of $\Delta \mathrm{K}$ (Evanno et al., 2005). The proportion of each individual genotype (q) in the predefined populations in each cluster was also estimated. Tests for the assignment and exclusion of populations as the original one for a given individual were performed using Bayesian methods (Rannala and Mountain, 1997) and were computed using the GENECLASS 2.0 software (Piry et al., 2004).

\section{RESULTS}

\section{Genetic diversity and HWE}

In the present study, the genetic polymorphisms, structure, and relationships among 
9 commercial cattle breeds raised in Brazil were analyzed. For the survey, we used a set of 11 microsatellite markers recommended by ISAG (FAO, 2011). A group of 2965 animals belonging to the breeds Brahman, Nelore, Tabapuã, Senepol, Girolando, Gyr, Guzerat, Holstein, and Jersey was analyzed.

The genetic parameters per locus analyzed in this study are shown in Table 1. It was detected 144 alleles over all loci surveyed, giving an average number of 13.1 alleles per locus. The $N_{\mathrm{A}}$ per locus varied from 9 at BM1824 and SPS115 to 22 at TGLA122 and TGLA53 (Table 1). All markers showed high levels of heterozygosity $(>0.60)$, except for ETH3, which generated $H_{\mathrm{O}}$ and $H_{\mathrm{E}}$ values of 0.57 and 0.58 , respectively. The overall mean inbreeding within populations $\left(F_{\mathrm{IS}}\right)$ over all loci was not significantly different from zero $(0.003 \pm 0.012)$. Nonetheless, the amount of differentiation among the populations, as estimated both under the infinitesimal model $\left(F_{\mathrm{ST}}\right)$ and the step-wise mutation model $\left(\mathrm{R}_{\mathrm{ST}}\right)$, was significant $(\mathrm{P}<0.01)$, with an overall mean of 0.147 and 0.161 , respectively. Only five markers (BM2113, ETH10, SPS115, TGLA122, and TGLA53) contributed significantly to breed differentiation, as suggested by the $F_{\mathrm{ST}}$. The BM1824 locus deviated from HWE in only two populations $(\mathrm{P}<0.05)$, whereas both SPS115 and TGLA126 deviated from HWE in eight populations.

\begin{tabular}{|c|c|c|c|c|c|c|c|c|}
\hline Locus & $N_{\mathrm{A}}$ & $H_{\mathrm{o}}$ & $H_{\mathrm{E}}$ & HWE & $F_{\mathrm{IT}}(\mathrm{SD})$ & $F_{\mathrm{ST}}(\mathrm{SD})$ & $F_{\text {IS }}(\mathrm{SD})$ & $R_{\mathrm{ST}}$ \\
\hline BM1824 & 9 & 0.64 & 0.65 & 2 & $0.08(0.03)$ & $0.08(0.03)$ & $0.01(0.03)$ & 0.08 \\
\hline BM2113 & 12 & 0.64 & 0.70 & 7 & $0.15(0.04)^{*}$ & $0.13(0.04)^{*}$ & $0.03(0.01)$ & 0.14 \\
\hline ETH10 & 10 & 0.62 & 0.61 & 5 & $0.29(0.05)^{*}$ & $0.27(0.05)^{*}$ & $0.02(0.02)$ & 0.47 \\
\hline ETH225 & 12 & 0.61 & 0.62 & 4 & $0.28(0.07)^{*}$ & $0.18(0.09)$ & $0.13(0.07)$ & 0.20 \\
\hline ETH3 & 12 & 0.57 & 0.58 & 3 & $0.18(0.11)$ & $0.17(0.09)$ & $0.01(0.05)$ & 0.43 \\
\hline INRA23 & 12 & 0.70 & 0.71 & 3 & $0.09(0.05)$ & $0.10(0.04)$ & $-0.01(0.02)$ & 0.06 \\
\hline SPS115 & 9 & 0.70 & 0.67 & 8 & $0.10(0.03)^{*}$ & $0.11(0.03)^{*}$ & $-0.01(0.03)$ & 0.14 \\
\hline TGLA122 & 22 & 0.82 & 0.79 & 7 & $0.06(0.03)$ & $0.10(0.03)^{*}$ & $-0.04(0.01)$ & 0.09 \\
\hline TGLA126 & 11 & 0.70 & 0.70 & 8 & $0.70(0.05)$ & $0.11(0.04)$ & $-0.05(0.02)^{*}$ & 0.17 \\
\hline TGLA227 & 13 & 0.61 & 0.61 & 4 & $0.19(0.07)$ & $0.18(0.07)$ & $0.00(0.02)$ & 0.59 \\
\hline TGLA53 & 22 & 0.80 & 0.76 & 7 & $0.08(0.02) *$ & $0.09(0.02) *$ & $-0.01(0.01)$ & 0.03 \\
\hline
\end{tabular}

Parameters estimated per microsatellite locus across nine Brazilian cattle breeds. $N_{\mathrm{A}}=$ number of alleles; $H_{\mathrm{O}}=$ observed heterozygositiy; $H_{\mathrm{E}}=$ expected heterozygosity; $\mathrm{HWE}=$ number of breeds showing deviations from Hardy-Weinberg equilibrium; $F_{\text {IT }}(F)=$ global deficit of heterozygotes; $F_{\mathrm{ST}}$ (theta) = amount of differentiation among populations; $F_{\mathrm{IS}}(f)=$ amount of inbreeding within populations; $\mathrm{SD}=$ standard deviation; $R_{\mathrm{ST}}=$ population differentiation detected by the marker locus under the step-wise model. $* \mathrm{P}<0.05$.

Measures of genetic variability within the breeds are shown in Table 2. The mean allelic richness per locus corrected for the sample size of each breed (R) ranged from 5.27 (Jersey) to 8.29 (Girolando). All breeds showed high levels of heterozygosity $(>0.60)$, except for Jersey, which showed $H_{\mathrm{E}}$ and $H_{\mathrm{O}}$ values of 0.58 and 0.59 , respectively. The $F_{\text {IS }}$ values indicated that 3 breeds (Holstein, Guzerat, and Nelore) presented with a significant deficit of heterozygotes. Conversely, 4 breeds (Brahman, Girolando, Senepol, and Tabapuã) presented with a significant excess of heterozygotes when compared to the expected values. Nine loci presented with significant deviations, as determined from the exact tests, from the expected Hardy-Weinberg proportions $(\mathrm{P}<0.05)$ in 4 breeds $(\mathrm{Gyr}$, Girolando, Nelore, and Senepol). Meanwhile, only 2 loci deviated significantly from HWE in the breeds Jersey and Tabapuã. 
Table 2. Genetic parameters measured per population.

\begin{tabular}{lrrrccccc}
\hline Breed & \multicolumn{1}{c}{$\mathrm{N}$} & $\mathrm{MNA}(\mathrm{SD})$ & $N_{\mathrm{E}}(\mathrm{SD})$ & $\mathrm{R}(\mathrm{SD})$ & $H_{\mathrm{E}}(\mathrm{SD})$ & $H_{\mathrm{O}}(\mathrm{SD})$ & $F_{\mathrm{IS}}$ & $\mathrm{HWE}$ \\
\hline Brahman & 466 & $7.82(3.19)$ & $3.50(0.50)$ & $5.90(2.07)$ & $0.66(0.13)$ & $0.68(0.14)$ & $-0.02^{*}$ & 7 \\
Gyr & 423 & $8.09(2.81)$ & $3.13(0.37)$ & $5.87(1.92)$ & $0.63(0.15)$ & $0.64(0.16)$ & -0.01 & 9 \\
Girolando & 66 & $8.82(2.18)$ & $5.29(0.45)$ & $8.29(2.07)$ & $0.80(0.07)$ & $0.86(0.08)$ & $-0.07 *$ & 9 \\
Guzerat & 371 & $8.18(2.44)$ & $3.49(0.35)$ & $6.43(1.82)$ & $0.67(0.14)$ & $0.65(0.15)$ & $0.03 *$ & 6 \\
Holstein & 169 & $8.36(2.29)$ & $3.95(0.35)$ & $6.78(1.84)$ & $0.71(0.10)$ & $0.67(0.11)$ & $0.05 *$ & 5 \\
Jersey & 38 & $5.27(1.01)$ & $2.65(0.29)$ & $5.27(1.01)$ & $0.58(0.17)$ & $0.59(0.20)$ & -0.01 & 2 \\
Nelore & 1095 & $10.00(4.12)$ & $3.00(0.26)$ & $6.39(2.08)$ & $0.64(0.90)$ & $0.63(0.12)$ & $0.02 *$ & 9 \\
Senepol & 299 & $6.91(2.02)$ & $3.15(0.34)$ & $5.91(1.62)$ & $0.63(0.17)$ & $0.65(0.19)$ & $-0.03 *$ & 9 \\
Tabapuã & 38 & $6.73(2.28)$ & $3.83(0.39)$ & $6.73(2.28)$ & $0.72(0.09)$ & $0.74(0.13)$ & $-0.02 *$ & 2 \\
\hline
\end{tabular}

Parameters estimated using 11 microsatellites in 9 Brazilian commercial breeds. $\mathrm{N}$ = number of individuals per population; $\mathrm{MNA}=$ mean number of alleles/locus; $N_{\mathrm{E}}=$ mean effective number of alleles/locus; $\mathrm{R}=$ mean allelic richness per locus corrected for sample size and breed corresponding to a minimum sample size of 38 individuals; $H_{\mathrm{E}}=$ mean expected heterozygosity; $H_{\mathrm{O}}=$ mean observed heterozygosity; $F_{\mathrm{IS}}=$ within-population inbreeding coefficient and its confidence interval; $\mathrm{HWE}=$ number of loci with Hardy-Weinberg equilibrium deviations; $\mathrm{SD}=$ standard deviation. $* \mathrm{P}<0.05$.

\section{Genetic distances and relationships among populations}

Allele frequencies were used to calculate pairwise $F_{\mathrm{ST}}$ values and the Nei DA genetic distances for each pair of the nine cattle populations (Table 3 ). All $F_{\mathrm{ST}}$ values were significantly different from zero $(\mathrm{P}<0.05)$, ranging from 0.042 in the Tabapuã/Nelore pair to 0.312 between the Jersey and Guzerat breeds. A good correlation between pairwise $F_{\mathrm{ST}}$ values and the Nei DA genetic distances was observed. As expected, higher differentiation was observed between pairs of European taurine and Indian zebuine breeds.

Table 3. Pairwise population genetic distance values among 9 Brazilian cattle breeds.

\begin{tabular}{lccccccccc}
\hline Breeds & Brahman & Gyr & Girolando & Guzerat & Holstein & Jersey & Nelore & Senepol & Tabapuã \\
\hline Brahman & - & 0.150 & 0.271 & 0.122 & 0.487 & 0.512 & 0.127 & 0.412 & 0.142 \\
Gyr & 0.090 & - & 0.221 & 0.117 & 0.492 & 0.505 & 0.151 & 0.411 & 0.166 \\
Girolando & 0.131 & 0.115 & - & 0.245 & 0.112 & 0.333 & 0.268 & 0.299 & 0.267 \\
Guzerat & 0.060 & 0.067 & 0.123 & - & 0.456 & 0.483 & 0.106 & 0.341 & 0.121 \\
Holstein & 0.239 & 0.257 & 0.048 & 0.222 & - & 0.276 & 0.440 & 0.333 & 0.445 \\
Jersey & 0.274 & 0.305 & 0.151 & 0.312 & 0.134 & - & 0.483 & 0.406 & 0.502 \\
Nelore & 0.088 & 0.112 & 0.139 & 0.080 & 0.221 & 0.260 & - & 0.354 & 0.099 \\
Senepol & 0.233 & 0.252 & 0.173 & 0.208 & 0.207 & 0.270 & 0.220 & - & 0.383 \\
Tabapuã & 0.060 & 0.084 & 0.088 & 0.051 & 0.187 & 0.254 & 0.042 & 0.208 & - \\
\hline
\end{tabular}

Nei Da distances (Nei et al., 1983) are shown above diagonal. Pairwise $F_{\mathrm{ST}}$ values are shown below diagonal. All estimates of $F_{\mathrm{ST}}$ were significant $(10,000$ permutations; $\mathrm{P}<0.05)$.

A phylogenetic construction based on the Nei DA genetic distance using the Neighbor-Net method was also constructed (Figure 1). Notably, genetic differentiation among the zebuine breeds was lower than among the taurine breeds. The Jersey and Holstein European taurine breeds clustered together in a separate clade. This also occurred for the Indian zebuine breeds Gyr and Guzerat. Close to the Indian zebuine breeds, we found the American zebuine derivatives Nelore, Tabapuã, and Brahman, which were placed in neighboring branches. Conversely, the American taurine breed Senepol and the American taurine/zebuine crossbreed Girolando were allocated separately in distinct branches. 


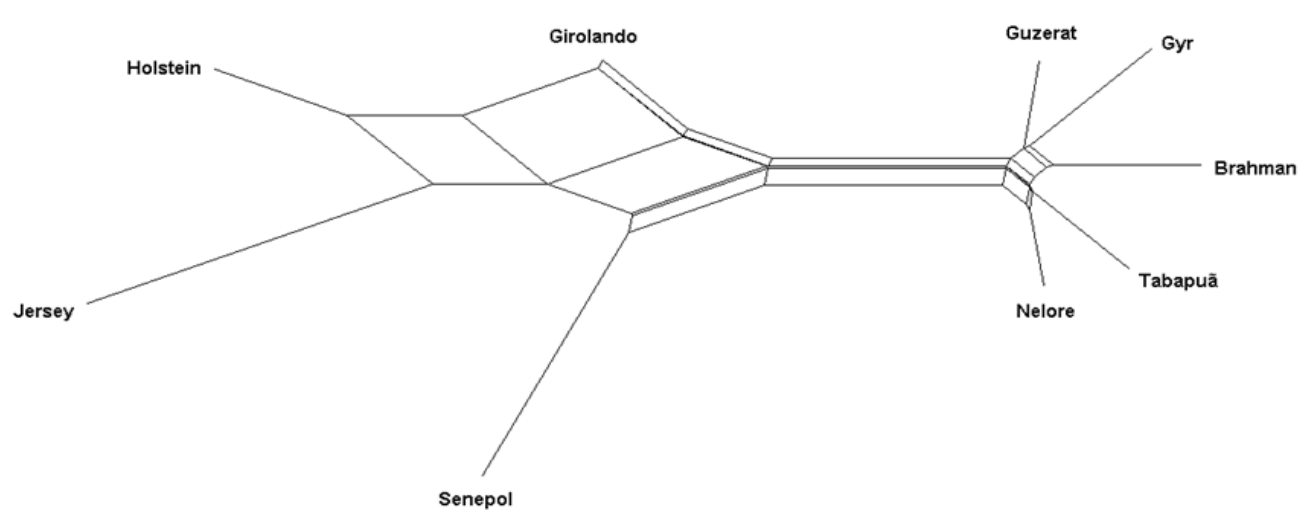

Figure 1. Neighbor-Net dendrogram constructed from the Nei DA genetic distances among 9 Brazilian cattle breeds. Nei DA (Nei et al., 1983) genetic distance measures were obtained using the GENECLASS 2.0 (Piry et al., 2004) and subsequently loaded into SPLITSTREE 4 software (Huson and Bryant, 2006) to graphically represent the relationships between breeds.

\section{Population genetic structure and admixture patterns}

AMOVA showed that $14.72 \%(\mathrm{P}<0.01)$ of the genetic variability was distributed among the breeds, while $85.28 \%$ was found within the breeds (Table 4 ). In addition, we performed a structural analysis using a Bayesian method to assign individuals to groups based on their genetic similarity. This approach was performed with increasing numbers of inferred populations (Figure 2). The membership of individual genotypes for $\mathrm{K}=2$ separated the taurine and zebuine breeds into 2 different clusters. Clear patterns of admixture were observed in the Girolando taurine/zebuine synthetic crossbreed. With $\mathrm{K}=3$, i.e., the most likely number of ancestral populations, the Nelore breed formed an independent cluster. Directional mating between Nelore and other Zebuine breeds also contributed to the formation of the Tabapuã breed. With $K=9$, most of the breeds clustered separately, except for Holstein and Jersey. In addition, signs of genetic introgression were observed among several breeds, especially those with a zebuine origin. Of note, the Nelore breed showed the most heterogeneous pattern of admixture, with contributions of at least 3 major groups. The assignment test using the 9 breeds yielded an average of $95.44 \%(\mathrm{~N}=2830)$ frequency of correctly assigned animals (Table 5). Only the synthetic crossbreed Girolando presented with frequencies lower than $90 \%$ of correctly assigned animals. Brahman, Gyr, Holstein, and Jersey breeds showed more than $95 \%$ of correctly assigned animals.

Table 4. Partitioning of genetic variability among 9 Brazilian cattle breeds.
\begin{tabular}{lrcccc}
\hline Source of variation & d.f. & Sum of squares & Variance components & Percentage of variation & Fixation index \\
\hline Among populations & 8 & 2940.142 & 0.62251 & 14.72 & $F_{\text {ST: }}$ 0.14723* \\
Within populations & 5921 & 21348.831 & 3.60561 & 85.28 & - \\
\hline
\end{tabular}

Genetic variation was partitioned in hierarquical groups by an analysis of molecular variance (AMOVA). $* \mathrm{P}<0.01$ $(10,000$ permutations $)$. d.f. $=$ degrees of freedom. $F_{\mathrm{ST}}=$ amount of differentiation among populations. 


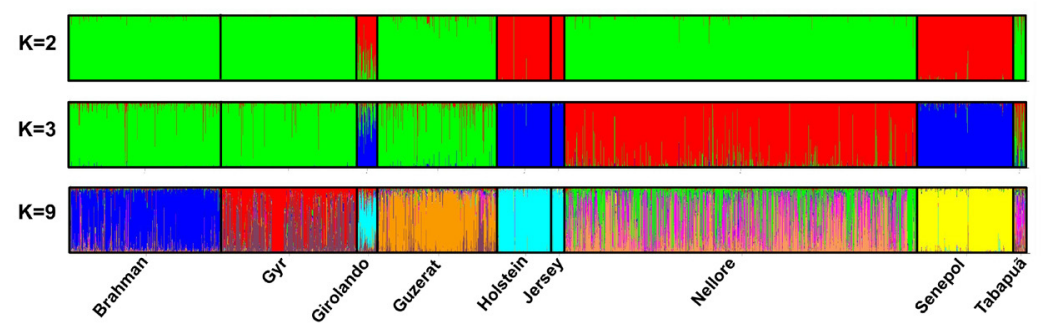

Figure 2. Population structure of 9 cattle populations using the model-based STRUCTURE software. Each animal is represented by a single vertical line divided into $\mathrm{K}$ colors, where $\mathrm{K}$ is the number of clusters assumed and the colors show the estimated individual proportions of cluster membership. Results are shown for $\mathrm{K}=2, \mathrm{~K}=3$, and $\mathrm{K}=9$.

Table 5. Population assignment analysis.

\begin{tabular}{lcc}
\hline Breed & Frequency of correctly assigned $(\mathrm{N})$ & Frequency of incorrectly assigned (N) \\
\hline Brahman & $96.78 \%(451)$ & $3.22 \%(15)$ \\
Gyr & $95.98 \%(406)$ & $4.02 \%(17)$ \\
Girolando & $87.87 \%(58)$ & $12.12 \%(8)$ \\
Guzerat & $93.53 \%(347)$ & $6.47 \%(24)$ \\
Holstein & $97.6 \%(165)$ & $2.4 \%(4)$ \\
Jersey & $97.36 \%(37)$ & $2.64 \%(1)$ \\
Nelore & $94.42 \%(1034)$ & $5.57 \%(61)$ \\
Senepol & $99.33 \%(297)$ & $0.67 \%(2)$ \\
Tabapuã & $92.1 \%(35)$ & $7.9 \%(3)$ \\
Total & $95.44 \%(2830)$ & $4.56 \%(135)$ \\
\hline
\end{tabular}

Assignment test estimated using the Bayesian method (Rannala and Mountain, 1997) implemented in the GENECLASS 2 software (Piry et al., 2004).

\section{DISCUSSION}

European cattle were introduced to Brazil $\sim 500$ years ago. Nonetheless, large-scaled commercial production systems were established only after the importation of zebuine breeds from India in the late 19th and 20th centuries (Cervini et al., 2006). Adapted to the tropical ecological settings found in Brazil, zebuine cattle rapidly became prominent in most herds and contributed to the development of new American breeds such as Nelore, Tabapuã, Indubrazil, and Girolando (Dani et al., 2008). Other conspicuous commercial breeds raised in Brazil, such as Brahman and Senepol, were also formed during the last century, although in other countries of the American continent (Novoa and Usaquén, 2010). In recent years, few reports have comprehensively detailed the genetic variability of the recently formed important commercial breeds ( $\sim 100$ years) in the Americas described in this study.

The high genetic variability found in recently developed American breeds (Table 2) may reflect the contributions of cattle from distinct origins to the breed composition. These animals resulted, in the large part, from absorbing crossbreeding between zebuine bulls imported from different regions of India and local taurine dams (Mariante et al., 1999). Furthermore, Brazilian Creole cattle also contributed to the formation of some American derivatives of zebuine breeds (such as Tabapuã) (Mariante et al., 1999; Dani et al., 2008). It has been shown that Latin American Creole breeds may carry either European- or Africanoriginated taurine DNA (Lirón et al., 2006; Ginja et al., 2010).

The global deficit of heterozygotes $\left(F_{\mathrm{IT}}\right)$ was significantly high for 5 markers, mostly 
due to breed genetic differentiation than to inbreeding (Table 1). The deviations from HWE also appear to be due to limited gene flow among breeds rather than to inbreeding. This evidence suggested that the effective population number of the analyzed breeds might be considerably large. The highest $F_{\text {IS }}$ values observed for the specialized exotic breeds Guzerat and Holstein (Table 2) were consistent with the history of intense artificial selection within these populations (Mariante et al., 1999).

The dendrogram based on the Nei DA genetic distance measures (Figure 1) presents the Senepol breed in an isolated clade among taurine populations. This probably reflects its unique origin among the populations analyzed. This breed was formed through crossings between the African taurine breed N'Dama with the European taurine breed Red Poll (www. senepolcattle.com). The development of this breed was favored by isolation, since it took place on the Caribbean Island of St. Croix during the early 20th century. Analysis of variance also reflected the origin of the Girolando population. In the dendrogram, this breed appears halfway between the European taurine and Indian zebuine breeds instead of being observed in a separate branch (Figure 1). However, this was not unexpected since the Girolando breed is derived from matings of Holstein with Gyr animals, usually at an admixture proportion of 5:8, respectively (Bicalho et al., 2006).

The data also show greater genetic differentiation among taurine cattle than among zebuine cattle raised in Brazil. This pattern probably reflects the way these 2 groups were introduced and are currently managed in the country. No specific breed classification was used during the first decades of the introduction of zebuine cattle, and all animals coming from India were generically classified as zebu (Santiago, 1985). The racial standards for zebuine breeds were only described and implemented in 1938 (Josahkian, 2000). Therefore, genetically pure herds directly descended from imported animals of both genders and without taurine gene introgression are very rare nowadays (Mariante et al., 1999). This last hypothesis was corroborated by the melted pattern of admixture observed for the zebuine breeds in Bayesian analysis conducted using STRUCTURE (Figure 2). This pattern was also reported for several Latin American Creole cattle breeds (Egito et al., 2007; Delgado et al., 2012).

Zebuine breeds display complex admixture patterns (Figure 2), particularly the Nelore and Tabapuã breeds. They were identified as a separate cluster from the other zebuine breeds (Figure 2, K = 3) and presented with significant contributions from several ancestral groups (Figure 2, K = 9). This was expected for the Tabapuã breed since it was developed at the beginning of the 20th century from crossings of a Creole taurine population called Mocho Nacional with zebuine breeds, mostly Nelore.

Conversely, Nelore is descended from animals of the Ongole breed imported from different parts of India during the 19th and 20th centuries. Once in Brazil, these animals received varying degrees of gene introgression from other local breeds at several farms, giving raise to distinct Nelore lineages (www.nelore.org.br). Additionally, a possible explanation for the complex admixture pattern of the Nelore population is a phenotype bias. White-coated, shorteared cattle have frequently been regarded as Nelore cattle by breeders in Brazil, regardless of their different geographic origins in India or their diverse genetic background (Dani et al., 2008). As a result, traditional selection based on phenotype alone is likely to have contributed to a significant melting among these different cattle over time. The significantly positive $F_{\text {Is }}$ values observed for the Nelore breed (Table 2) might also point to the contribution of more than one population within this breed. The observation that gene flow and gene segregation still play a major role in maintaining genetic variability within the Nelore population in Brazil is in 
accordance with the study of Dani et al. (2008). These authors proposed that the classification of this breed should be reviewed and at least two major sub-groups created.

Interestingly, the Brahman breed, which was formed in the south of the USA with parental breed contributions from Nelore, Gyr, and mainly Guzerat (Novoa and Usaquén, 2010), presented with lower levels of admixture when compared to other zebuine breeds (Figure 2).

Despite the significant gene introgression observed, especially among the zebuine breeds, Bayesian population assignment analysis correctly identified most groups with more than $90 \%$ accuracy (Table 5).

Taken together, the data presented here show that significant diversity has been partitioned among the breeds developed in the American continent during the last 100 years. This shows that, despite their relatively recent formation, these breeds comprise distinct cattle subpopulations and therefore act as important resources of genetic diversity in the tropics. In addition, the gene flow and gene segregation observed among the zebuine breeds raised in Brazil, especially in the Nelore and Tabapuã populations, might constitute major barriers to genetic improvement programs, since these phenomena favor random variability instead of standardization. Therefore, this study reinforces the importance of the systematic use of molecular markers to guide comprehensive management, genealogic records, and breeding programs for these populations.

\section{ACKNOWLEDGMENTS}

Research supported by the Brazilian agencies CNPq (INCT \#573899/2008-8) and FAPEMIG (INCT \#APQ-0084/08).

\section{REFERENCES}

Bicalho HM, Pimenta CG, Mendes IK, Pena HB, et al. (2006). Determination of ancestral proportions in synthetic bovine breeds using commonly employed microsatellite markers. Genet. Mol. Res. 5: 432-437.

Cervini M, Henrique-Silva F, Mortari N and Matheucci E Jr (2006). Genetic variability of 10 microsatellite markers in the characterization of Brazilian Nellore cattle (Bos indicus). Genet. Mol. Biol. 29: 486-490.

Dani MA, Heinneman MB and Dani SU (2008). Brazilian Nelore cattle: a melting pot unfolded by molecular genetics. Genet. Mol. Res. 7: 1127-1137.

Delgado JV, Martínez AM, Acosta A, Alvarez LA, et al. (2012). Genetic characterization of Latin-American Creole cattle using microsatellite markers. Anim. Genet. 43: 2-10.

Egito AA, Paiva SR, Albuquerque MS, Mariante AS, et al. (2007). Microsatellite based genetic diversity and relationships among ten Creole and commercial cattle breeds raised in Brazil. BMC Genet. 8: 83.

Evanno G, Regnaut S and Goudet J (2005). Detecting the number of clusters of individuals using the software STRUCTURE: a simulation study. Mol. Ecol. 14: 2611-2620.

Excoffier L, Laval G and Schneider S (2005). Arlequin (version 3.0): an integrated software package for population genetics data analysis. Evol. Bioinform. Online 1: 47-50.

Excoffier L, Smouse PE and Quattro JM (1992). Analysis of molecular variance inferred from metric distances among DNA haplotypes: application to human mitochondrial DNA restriction data. Genetics 131: 479-491.

FAO (Food and Agricultural Organization) (2011). Molecular Genetic Characterization of Animal Genetic Resources, FAO Animal Production and Health Guidelines. FAO, Rome.

Ginja C, Penedo MC, Melucci L, Quiroz J, et al. (2010). Origins and genetic diversity of New World Creole cattle: inferences from mitochondrial and Y chromosome polymorphisms. Anim. Genet. 41: 128-141.

Goudet J (1995). Fstat (version 2.9.3.): a computer program to calculate F-statistics. J. Hered. 86: 485-486.

Huson DH and Bryant D (2006). Application of phylogenetic networks in evolutionary studies. Mol. Biol. Evol. 23: 254-267.

Jaeger LG (1943). Separata da Revista do Instituto Histórico e Geográfico do Rio Grande do Sul, II Trimestre de 1943, 
Ano XXIII. In: História da Introdução do Gado no Rio Grande do Sul (1634) Ofício Gráfico da Imprensa Oficial, Porto Alegre, 127-245.

Josahkian L (2000). Programa de Melhoramento Genético das Raças Zebuínas. In: III Simpósio Nacional de Melhoramento Animal Belo Horizonte, MG, Brasil.

Li MH and Kantanen J (2010). Genetic structure of Eurasian cattle (Bos taurus) based on microsatellites: clarification for their breed classification. Anim. Genet. 41: 150-158.

Li MH, Tapio I, Vilkki J, Ivanova Z, et al. (2007). The genetic structure of cattle populations (Bos taurus) in northern Eurasia and the neighbouring Near Eastern regions: implications for breeding strategies and conservation. Mol. Ecol. 16: 3839-3853.

Lirón JP, Bravi CM, Mirol PM, Peral-Garcia P, et al. (2006). African matrilineages in American Creole cattle: evidence of two independent continental sources. Anim. Genet. 37: 379-382.

Mariante AS, Albuquerque MSM, Egito AA and McManus C (1999). Advances in the Brazilian animal genetic resources conservation programme. Anim. Genet. Resour. Inform. 25: 107-121.

Miller SA, Dykes DD and Polesky HF (1988). A simple salting out procedure for extracting DNA from human nucleated cells. Nucleic Acids Res. 16: 1215

Nei M (1973). Analysis of gene diversity in subdivided populations. Proc. Natl. Acad. Sci. U. S. A. 70: 3321-3323.

Nei M, Tajima F and Tateno Y (1983). Accuracy of estimated phylogenetic trees from molecular data. II. Gene frequency data. J. Mol. Evol. 19: 153-170.

Novoa MA and Usaquén W (2010). Population genetic analysis of the Brahman cattle (Bos indicus) in Colombia with microsatellite markers. J. Anim. Breed. Genet. 127: 161-168.

Park S (2002). Trypanotolerance in West African Cattle and the Population Genetics Effects of Selection. Doctoral thesis, The University of Dublin, Dublin, Ireland.

Piry S, Alapetite A, Cornuet JM, Paetkau D, et al. (2004). GENECLASS2: a software for genetic assignment and firstgeneration migrant detection. J. Hered. 95: 536-539.

Pritchard JK, Stephens M and Donnelly P (2000). Inference of population structure using multilocus genotype data. Genetics 155: 945-959.

Rannala B and Mountain JL (1997). Detecting immigration by using multilocus genotypes. Proc. Natl. Acad. Sci. U. S. A. 94: 9197-9201.

Salazar J and Cardozo A (1986). Desarrollo del Ganado Criollo en América Latina: Resumen Histórico y Distribución Actual. In: Ganado Bovino Criollo. Orientación Gráfica. Buenos Aires, 164-169.

Santiago A (1985). O Zebu na Índia, no Brasil e no Mundo. Instituto Campineiro de Ensino Agrícola, Campinas.

Tapio I, Varv S, Bennewitz J, Maleviciute J, et al. (2006). Prioritization for conservation of northern European cattle breeds based on analysis of microsatellite data. Conserv. Biol. 20: 1768-1779.

Weir B and Cockerham C (1984). Estimating F-statistics for the analysis of population structure. Evolution 38: 1358-1370. 